\title{
Systematic Literature Review of Flipped Classroom in Mathematics
}

\author{
Chak-Him Fung $^{1 *}$, Michael Besser ${ }^{2}$, Kin-Keung Poon ${ }^{1}$ \\ ${ }^{1}$ The Education University of Hong Kong, HONG KONG \\ 2 Leuphana Universität Lüneburg, GERMANY
}

Received 3 February 2021 - Accepted 23 April 2021

\begin{abstract}
Flipped classroom, which is also known as "inverted classroom", is an instructional strategy and a type of blended learning. It reverses the traditional teaching and learning approach by delivering the instructional content, often by video, outside the classroom and filling the in-class with different activities such as discussion. Since it has been coined in the late 1990s, its effect on students' learning outcomes has been fallen into a debate. Inconsistency of the use of in-class activities is one of the main reasons for the difficulties in making comparisons. This study systematically reviewed the current articles $(n=12)$ of flipped classroom in mathematics to investigate the effect of flipped classroom (and their in-class activities adopted) on mathematics learning. Results indicated that the effect of flipped classroom in mathematics is still ambiguous in terms of students' academic performance and perceptions. Further investigation showed that effective flipped classroom, which yielded a better academic result than the traditional approach, always consists of discussion, teachers' feedbacks and peer-collaborative work. A framework of effective flipped classroom in mathematics is then suggested.
\end{abstract}

Keywords: flipped classroom, mathematics, literature review, performance and perceptions, framework

\section{INTRODUCTION}

\section{What is Flipped Classroom?}

With advanced technology development, psychologists started to review and challenge the most traditional teaching and learning approach substantively (Crouch \& Mazur, 2001; King, 1993; Mazur, 1997). By using video as a pre-class learning activity, a new teaching and learning strategy is created. The word "Flipping Classroom" was then coined in the late 1990s (e.g., Baker, 2000). It soon became one of the popular issues in education (e.g., Bernard, 2015; Bishop \& Verleger, 2013; Chua \& Lateef, 2014; Giannakos, Krogstie, \& Chrisochoides, 2014; O'Flaherty \& Phillips, 2015; Zainuddin \& Halili, 2016; Zuber, 2016).

Flipped classroom is also known as "inverted classroom” (Sahin, Cavlazogula, \& Zeytuncu, 2015). As one type of flipped learning, flipped classroom also has its traditional lecture done before class while homework finished in-class (Bergmann \& Sams, 2012; Pierce \& Fox, 2012; Roehl, Reddy, \& Shannon 2013). According to
Bishop and Verleger (2013), flipped classroom is "an educational technique that consists of two parts: interactive group learning activities inside the classroom, and direct computer-based individual instruction outside the classroom" (para. 13).

\section{What is its Significance in Education?}

Educators generally believe that flipped classroom could enhance students' learning (Dove \& Dove, 2017; Gilboy, Heinerichs, \& Pazzaglia, 2015; Gross, Marinari, Hoffman, DeSimone, \& Burke, 2015; Isabel, Stefan, \& Mikko, 2014; Roehl et al., 2013). Due to the use of a more student-centred learning approach, students are free to interact with the learning context according to their own learning pace (Roehl et al., 2013). For instance, able students could skip the video and search for extra learning materials from the internet while the lower achiever could study the content with repetition (Dove \& Dove, 2017; Roehl et al., 2013). By shifting the lecture section out of the classroom, more in-class time could be spent on explaining difficult concepts or working on problems with guidance (Delozier \& Rhodes, 2017).

(c) 2021 by the authors; licensee Modestum. This article is an open access article distributed under the terms and conditions of the Creative Commons Attribution License (http://creativecommons.org/licenses/by/4.0/). 


\section{Contribution to the literature}

- This paper systematically reviewed the current articles of flipped classroom in mathematics to investigate the effect of flipped classroom and their in-class activities adopted on mathematics learning.

- From the reviews, this article showed that effective flipped classroom always consists of interactive activities such as discussion, teachers' feedbacks, and peer-collaborative work.

- This study also developed a framework for using flipped classroom in mathematics.

More individual guidance and students' special education needs could be provided (Bishop \& Verleger, 2013). Task value, critical thinking and peer instruction could also be improved although their duration may be short (Van Vliet, Winnips, \& Brouwer, 2015).

However, the effect of flipped classroom is still ambiguous. Although it is theoretically feasible, the evidences which support flipped classroom could enhance student's academic performance and perceptions are still weak (Bernard, 2015; Bishop \& Verleger, 2013; Chua \& Lateef, 2014; Giannakos et al., 2014; Lelean \& Edwards, 2020; O'Flaherty \& Phillips, 2015; Ward, Knowlton, \& Laney, 2018; Zainuddin \& Halili, 2016; Zuber, 2016). Educators believe that the inconsistent theoretical frameworks, methods, and inclass activities applied are the significant factors leading to such unclear result (Lin \& Hwang, 2018; Lo \& Hew, 2017a; Zuber, 2016). To draw a more certain conclusion, investigation of the flipped classroom's framework, methods and in-class activities applied should be done (Giannakos et al., 2014 Kostaras, 2017; Zuber, 2016).

\section{LITERATURE REVIEW}

Several reviews have been conducted in recent years in an attempt to explore and provide insights into the growing body of knowledge in flipped classroom. One of the first reviews was conducted by Zuber in 2016. By comparing the studies between 2012 and 2014, Zuber (2016) concluded that the effect of flipped classroom is unclear because different researchers had adopted different frameworks and different in-class activities in their actual practice. The results were thus not comparable. Ward et al. (2018) conducted a study of the effect of flipped classroom in nursing education by reviewing 14 studies. It was found that students generally believe that the flipped classroom is beneficial to their learning and understanding. About one-third of the studies had reported a positive academic improvement compared to the traditional lecture model. Although useful, the majority of students still prefer traditional lecture to flipped classroom. Lin and Hwang (2018) examined the research trend of flipped classroom studies for medical courses by reviewing 60 studies from 2008 to 2017. They found that the use of in-class activities was inconsistent in most studies. Discussion, doing exercises, problem-based activities and group project activities were the most popular in-class activities in flipped classroom in medical courses. However, nearly half of the studies adopted no technology component in their in-class activities.

Reviews have also been conducted on conference proceedings and dissertations. Giannakos et al. (2014) conducted a study in an attempt to summarise the significant achievement of flipped classroom in computer science education by examining 32 peerreviewed papers. They concluded that flipped classroom was effective in enhancing students' learning performance, attitude and engagement. Although its effect on the quality of the discussion was still unclear, the quantity of discussion increased, and the students' learning habits changed too. In a parallel study, Kostaras (2017) investigated the effect of flipped classroom on English learning by reviewing six studies. The result suggested that flipped classroom could enhance active learning, satisfaction and interactions among teachers and students.

Although some educators believed that flipped classroom could result in students' improvement in mathematics, the improvement is very weak (Lelean, and Edwards, 2020; Lo and Hew, 2017b; Strelan, Osborn \& Palmer, 2020; Van Alten, Phielix, Janssen, \& Kester, 2019; Wagner, Gegenfurtner, \& Urhahne, 2021). Recent reviews are still insufficient for undercover the mysteries of flipped classroom. Although three out of five reviews suggested that the current flipped classroom's framework, methods and in-class activities applied were still inconsistent and thus it hindered the effect comparison, none of them provided a comparison among those elements (see Giannakos et al., 2014; Kostaras, 2017; Zuber, 2016). The reverse of the lecture and homework sequence and the use of video were the main characteristics of the flipped classroom; however, they may not be the main reasons for the positive gains. If compared with the traditional lectures, the students' performance may be improved by the in-class components rather than the use of a reverse activitysequence or video (Zuber, 2016).

In the meantime, reviews according to individual discipline are needed because the effect of the flipped classroom may depend on the subject nature (Giannakos et al., 2014). According to Gafoor and Sarabi (2015), students usually perceive mathematics as a subject which is much more complicated than other subjects. Mathematics usually study concepts in abstract. More efforts are required in mathematics for understanding the symbols, notations, concepts in terms of their depth 


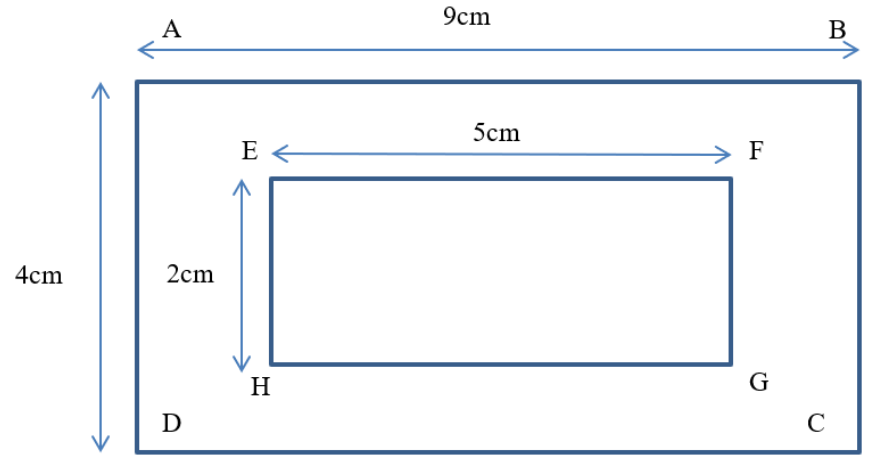

Figure 1. A modified question from a grade 10 Hong Kong Mathematics textbook

and precision (Gafoor \& Sarabi, 2015). Repeated practice and external supports, such as teachers' feedback and mathematical peer discussion, are required for students to organise their reasoning and justify their planning strategies (Gafoor \& Sarabi, 2015; Kosko \& Miyazaki, 2012; Vygotsky, 1978, 1987). Lets' take the topic "calculation of perimeter" as an example. Figure 1 is a question which is modified from one of questions in a grade 10 mathematics textbook in Hong Kong. Although it is just made up of two simple rectangles, the question is considered as one of the most difficult problems in grade 10 mathematics curriculum. Since perimeter refers to the total length which encompasses or surrounds a 2D shape, whether the inner perimeter (EF, FG, GH and EH) should be counted could provoke an issue among students (because some may think that $A B, B C, C D$ and DA have already surrounded the photoframe). To clarify this, the concept of closed shape must be mastered accurately and precisely. Students have to figure out that ABCDEFGH is a "closed shape" (e.g., by treating the inner rectangle as a "hole") so as to see the reason of including the inner perimeter in the perimeter of the photoframe. More efforts in understanding and practicing the pre-requisite concepts are required. Teacher and peer supports may also be required especially when the concepts are in abstract. Also, the increase of the amount of waiting time (Kosko \& Miyazaki, 2012), immediate feedback (Attali \& Van Der Kleij, 2017) and the teachers guidances (Webb et al., 2017) could improve the quality of the students' discussion in mathematics. In light of these, some activities or interactions, such as discussion and feedbacks, in flipped classroom may produce a more significant impact on students' academic performance in a subject than the others. However, recent studies which review the effect of flipped classroom in mathematics are very limited. This study would attempt to investigate the effect as well as to explore a framework for effective mathematics flipped classroom.

\section{RESEARCH QUESTIONS}

To investigate the effect of flipped classroom in mathematics, the following research questions were proposed.
1. Does flipped classroom have a positive impact on academic achievement among students in Mathematics?

2. Does flipped classroom have a positive impact on the perception among students in Mathematics?

3. What activity should be adopted in-class in an effective Mathematics flipped classroom?

4. What are the common practices of the use of preclass material in flipped classroom? What is the duration of them in the pre-class section?

\section{METHODOLOGY}

A systematic review presents a summary of literature which is summarised and analysed by using objective, explicit and replicable techniques (Cooper, 2010). To ensure the quality of this study, this systematic review followed the seven steps suggested by Cooper (2007). They include (1) formulating the problem; (2) searching the literature; (3) gathering information from studies; (4) evaluating the quality of studies; (5) analysing and integrating the outcomes of studies; (6) interpreting the evidence and (7) presenting the results.

The searching process started by a combination of keywords about flipped classroom by using ProQuest because it scans all the in-text vocabularies in articles among 18 databases so that it could cover the related articles more exhaustively. To widen the search, no limitation was set for the year of publication. The searching of ("Flipping classroom" AND mathematics) OR ("Flipped learning" AND mathematics) OR ("inverted classroom" AND mathematics) resulted in 818 articles.

To ensure the quality of the literature, abstracts were read thoroughly and literature which was not full-text assessable on the internet or peer-reviewed were discarded. 142 articles were then left. Due to the characteristics of the ProQuest data searching engine, articles focusing on non-flipping or non-mathematics may appear if they contain at least one of the key words in their in-text vocabularies. For example, an article focusing on engineering may appear because it contains a sentence "this framework is also feasible for teaching mathematics". Further filtering was then conducted. 
Frequency vs year of publication

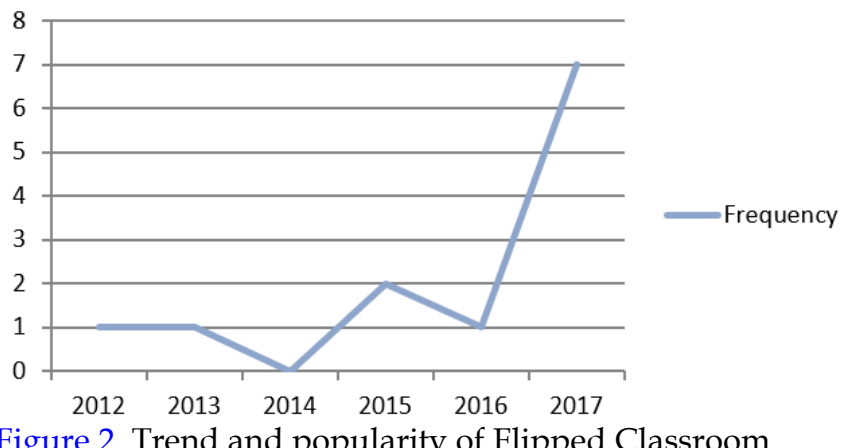

Figure 2. Trend and popularity of Flipped Classroom

\section{Distribution among countries/regions}

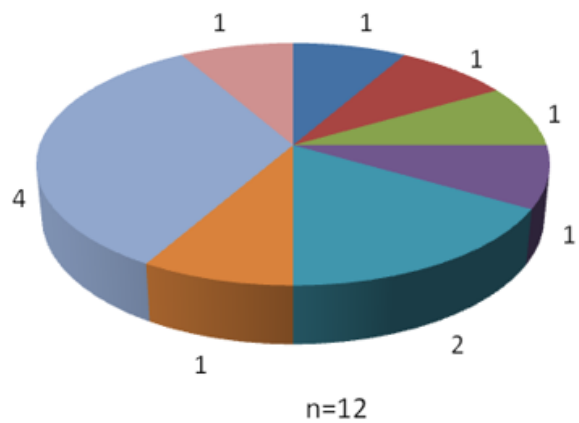

- Australia

- Hong Kong

- Iran

netherlands

- Taiwan

- Turkeys

USA

Not mentioned

Figure 3. Distribution of literatures among countries/regions

\section{Distribution of participants' level}

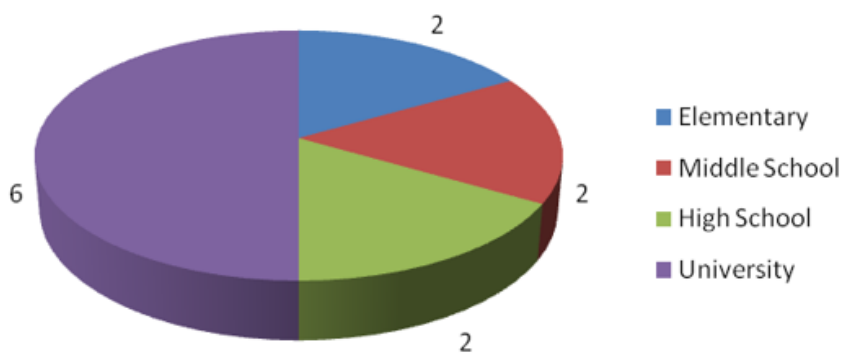

$n=12$

Figure 4. Distribution of literatures according to participants' level

Non-flipping articles, Non-mathematics articles, repeated articles and articles which were not written in English were eliminated. One additional study was further eliminated because it was not an empirical study. A total of 130 articles did not meet these criteria, leaving 12 articles to be included in this study.

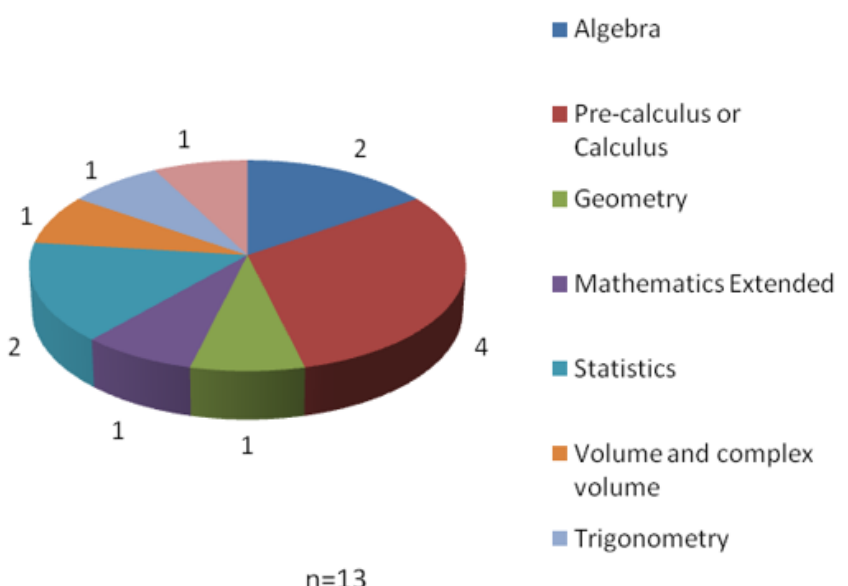

Distribution of topics

Figure 5. Distribution of topics among literatures ${ }^{1}$

\section{Handling of Data}

The articles were reviewed, and background information was shown in Appendix A and Figures 2-5. In order to answer RQ1 and RQ2, the empirical data and the in-class activity adopted in the articles were summarized and Tables 1 and 2 were made respectively. Due to different purposes in the literature, the original empirical data shown may not be ready for the use to this study and thus calculations (such as t-test) were made if necessary. For example, Hwang and Lai (2017) would like to find out the advantage of flipped classroom using e-book over traditional flipped classroom; hence, the $t$ test of the result was a comparison between them. To investigate the simple effect of flipped classroom, further calculations were made by using the statistics provided in the literature. For convenient purpose, positive effect $(+)$, no change $(0)$ and negative effect $(-)$ were used to describe the result of the empirical studies. " + " refers to a significant increase obtained by the sample group regardless to the types of experimental design while "-" refers to a significant decrease obtained by the sample group regardless to the types of experimental design. Meanwhile, " 0 " refers to an insignificant result or an unclear result. For details, please refer to the footnotes in the corresponding tables.

Based on the 12 selected articles, six different types of activities were identified. They are (1) in-class lecture; (2) solving problems or homework; (3) discussion; (4) feedback; (5) quiz; and (6) collaborative work. The inclass lecture referred to the strategy which teacher present the teaching material and conduct the lecture himself/herself to the students and try to deliver the knowledge directly from him/her to the students while the solving problems or homework referred to the strategy which students finish some exercises given by the teachers. In the meantime, Discussion and Feedback were

${ }^{1}$ One of the article contains two studies of two different topics. 
Table 1. Result of the effects on the academic performance in mathematics and in-class activities used in the literatures ${ }^{2}$

\begin{tabular}{|c|c|c|c|c|c|c|c|c|}
\hline \multirow[b]{2}{*}{ Articles } & \multirow[b]{2}{*}{$\begin{array}{l}\text { Intervention } \\
\text { in the } \\
\text { Control } \\
\text { group }\end{array}$} & \multirow[b]{2}{*}{$\begin{array}{l}\text { Empirical result }{ }^{3} \text { (Academic } \\
\text { performance) }\end{array}$} & \multirow[b]{2}{*}{$\begin{array}{l}\text { Interpretation of } \\
\text { the empirical } \\
\text { result (+: positive } \\
\text { effect; 0: no } \\
\text { change or unclear } \\
\text {-: negative effect) }\end{array}$} & \multicolumn{5}{|c|}{ Intervention of the sample group (in class) } \\
\hline & & & & Lecture & $\begin{array}{l}\text { Solving } \\
\text { problems } \\
\text { or } \\
\text { homework }\end{array}$ & $\begin{array}{l}\text { Discussion } \\
\text { / group } \\
\text { discussion }\end{array}$ & $\begin{array}{l}\text { Feedback } \\
\text { from } \\
\text { teachers }\end{array}$ & $\begin{array}{c}\text { Peer- } \\
\text { Quiz collaborative } \\
\text { work }\end{array}$ \\
\hline $\begin{array}{l}\text { Bhagat Chang, } \\
\text { and Chang (2016) } \\
\text { Yousefzadeh and } \\
\text { Salimi (2015) } \\
\end{array}$ & $\begin{array}{l}\text { Lecture, and } \\
\text { discussion } \\
\text { Exist, but } \\
\text { detail was } \\
\text { not } \\
\text { mentioned }\end{array}$ & $\begin{array}{l}F(1,79)=8.001, p<.05, \eta^{2}= \\
.092 \\
t=6.559 p=0.0012^{4}\end{array}$ & 0 & & $\bullet$ & $\bullet$ & $\bullet$ & • \\
\hline $\begin{array}{l}\text { Lo and Hew } \\
\text { (2017) }\end{array}$ & Nil & $\begin{array}{l}\text { Study } 1: \mathrm{t}(12)=6.50, \mathrm{p}<.0001 \\
\text { The Cohen's d value was } 1.80 \\
\text { Study } 2: \mathrm{t}(23)=9.43, \mathrm{p}<.0001 \\
\text { The Cohen's d value was } 1.92\end{array}$ & + & $\bullet$ & $\bullet$ & $\bullet$ & & $\bullet$ \\
\hline $\begin{array}{l}\text { Sahin, } \\
\text { Cavlazoglu, and } \\
\text { Zeytuncu (2015). }\end{array}$ & Nil & $\begin{array}{l}\mathrm{t}(94)=3.502, \mathrm{p}=.001(\mathrm{M}=8.32 \\
\mathrm{SD}=1.36)(\mathrm{M}=7.54, \mathrm{SD}=1.69) \\
\text { Cohen's d effect size and came } \\
\text { up with d as }-0.51\end{array}$ & + & & & & & $\bullet$ \\
\hline $\begin{array}{l}\text { Song and Kapur } \\
\text { (2017) }\end{array}$ & $\mathrm{TFC}^{5}$ & $\begin{array}{l}\text { Pre-test: } \mathrm{t}(1,48)=1.047, \mathrm{p}>.3 \\
\text { mid-test: } \mathrm{t}(1,48)=1.515, \mathrm{p}>.1 \\
\text { post-test: } \mathrm{t}(1,48)=0.626, \mathrm{p}>.5\end{array}$ & +6 & & • & $\bullet$ & & \\
\hline $\begin{array}{l}\text { Zengin (2017) } \\
\text { Hwang and Lai } \\
\text { (2017) }\end{array}$ & $\begin{array}{l}\text { nil } \\
\text { TFC }^{7}\end{array}$ & $\begin{array}{l}\mathrm{z}=-4.21, \mathrm{p}<.05, \mathrm{r}=-.62 \\
\mathrm{t}=2.43, \mathrm{p}<.05, \text { Cohen'd }=0.74\end{array}$ & $\begin{array}{l}+ \\
0^{8}\end{array}$ & & $\bullet$ & $\bullet$ & - & \\
\hline $\begin{array}{l}\text { Buch and Warren } \\
\text { (2017) }\end{array}$ & $\begin{array}{l}\text { Exists, but } \\
\text { detail was not } \\
\text { mentioned }\end{array}$ & $\begin{array}{l}\text { Lecture group average score } \\
\text { (Exam 1: 88\%, Exam 2: 64\%, } \\
\text { Exam 3: 73\%) } \\
\text { Flipped group average score } \\
\text { (Exam 1: } 90 \% \text {, Exam 2: } 77 \% \text {, } \\
\text { Exam 3: 66\%) }\end{array}$ & $0^{9}$ & & $\bullet$ & & & \\
\hline $\begin{array}{l}\text { McGivney-Burelle } \\
\text { and Xue (2013). }\end{array}$ & $\begin{array}{l}\text { direct } \\
\text { teaching }+ \\
\text { notes taking }\end{array}$ & $\begin{array}{l}\text { Lecture group score (Exam 1: } \\
76.24 \% \text {, Exam 2:71.27\%) } \\
\text { Flipped group score (Exam 1: } \\
77.48 \% \text {, Exam } 2: 76.48 \% \text { ) }\end{array}$ & $0^{10}$ & & $\bullet$ & & & \\
\hline
\end{tabular}

${ }^{*}$ Remarks: coloured areas represent the studies with a control group (tradition-lecture model).

defined as the "text as conversations during which participants ask and answer questions of each other and the text in order to construct meaning." (Reninger \& Rehark, 2009, p. 268) and the "information about the gap between the actual level and the reference level of a system parameter which is used to alter the gap in some way." (Ramaprasad, 1983, p. 4) respectively. Quiz referred to the strategy that a set of questions or problems which aimed at investigating some parameters (usually refers to the knowledge level or ability) of the participants. Moreover, collaborative work was defined as the...

shared, coordinated and interdependent process, in which students work together in order to achieve a common goal in a virtual environment and based on a process of activity, interaction and reciprocity between students, thus facilitating the collaborative

${ }^{2}$ For convenient comparison purpose, the articles are sorted by academic performance and the existence of a (non-flipping) control group (positive result \& with a control group, positive result \& without a control group, no change or unclear \& without a control group, no change or unclear \& with a control group. Since no negative result were reported, negative result \& with a control group and negative result \& without a control group are omitted) followed by the alphabetical order of the name of the first author.

${ }^{3}$ It represents the results which are directly indicated in the articles.

${ }^{4}$ The typing error " $t=0.0012$ " in the article is corrected as $t=6.559 \mathrm{p}=0.0012$.

${ }^{5}$ Song \& Kapur (2017) compared the effect between productive failure-based flipped classroom (PFFC) and traditional flipped classroom (TFC). TFC was assigned as the control group.

${ }^{6}$ Since the t-test compares only the effect between the PFFC and TFC, the effect of flipped classroom is calculated using the raw data provided in the articles.

${ }^{7}$ Hwang \& Lai (2017) compared the effect between flipped classroom using e-book and traditional flipped classroom (TFC). TFC was assigned as the control group.

8 The study did not originally compare the pre-test score with the post-test score in terms of the flipped classroom. Mini meta-analysis indicated a t-test of the sample and control group were -0.757 and -1.264 respectively while the t-test of the sum is -1.51 . The result was classified as unclear as the post-test scores were not significantly lower than the pre-test scores at $95 \%$ confidence interval.

${ }^{9}$ The study stated only the mean scores of three exams. Sometimes the sample score was higher while sometimes the control score was higher. The result was thus classified as unclear.

${ }^{10}$ The study stated only the means with very similar value. The result was classified as unclear. 
Table 2. Result of the effects on the students' perceptions in mathematics and in-class activities used in the literatures ${ }^{11}$

\begin{tabular}{|c|c|c|c|c|c|c|c|}
\hline Articles & $\begin{array}{l}\text { Intervention } \\
\text { in the } \\
\text { Control } \\
\text { group }\end{array}$ & Empirical result (Perception) & $\begin{array}{l}\text { Interpretation of } \\
\text { the empirical } \\
\text { result (+: positive } \\
\text { effect; -: negative } \\
\text { effect) }\end{array}$ & $\begin{array}{c}\text { Solving } \\
\text { Lecture }^{12} \text { problems or } \\
\text { homework }\end{array}$ & $\begin{array}{l}\text { Discussion } \\
\text { / group } \\
\text { discussion }\end{array}$ & $\begin{array}{l}\text { Feedback } \\
\text { from } \\
\text { teachers }\end{array}$ & $\begin{array}{c}\text { Peer- } \\
\text { Quiz collaborative } \\
\text { work }\end{array}$ \\
\hline $\begin{array}{l}\text { Bhagat Chang } \\
\text { and Chang } \\
\text { (2016) }\end{array}$ & $\begin{array}{l}\text { Lecture, } \\
\text { and } \\
\text { discussion }\end{array}$ & $\begin{array}{l}\text { Significant difference for attention, } \\
\text { relevance, confidence, and satisfaction } \\
\text { between the experimental and control } \\
\text { groups, Wilk's } \Lambda=.68, \mathrm{~F}=8.90, \mathrm{p}<.05 \text {, } \\
\eta 2=.31\end{array}$ & $\begin{array}{l}\text { Attention }(+) \\
\text { Relevance }(+) \\
\text { Confidence }(+) \\
\text { Satisfaction }(+)\end{array}$ & & - & - & $\bullet$ \\
\hline $\begin{array}{l}\text { Buch and } \\
\text { Warren (2017) }\end{array}$ & $\begin{array}{l}\text { Exists, no } \\
\text { detail was } \\
\text { mentioned }\end{array}$ & $\begin{array}{l}\text { Survey: } 91 \% \text { participants believe flipped } \\
\text { aid understanding }\end{array}$ & Confidence $(+)$ & - & & & \\
\hline $\begin{array}{l}\text { McGivney- } \\
\text { Burelle and Xue } \\
\text { (2013). }\end{array}$ & $\begin{array}{l}\text { direct } \\
\text { teaching + } \\
\text { notes taking }\end{array}$ & $\begin{array}{l}\text { "Students in the flipped unit also } \\
\text { appreciated the way in which class time } \\
\text { was used during the flipped unit of } \\
\text { study" (p.482) }\end{array}$ & Satisfaction $(+)$ & $\bullet$ & & & \\
\hline $\begin{array}{l}\text { Muir and Geiger } \\
\text { (2016) }\end{array}$ & & $\begin{array}{l}87 \% \text { participants believe they would } \\
\text { then do better in tests }\end{array}$ & Confidence (+) & $\bullet$ & $\bullet$ & $\bullet$ & \\
\hline $\begin{array}{l}\text { Sahin, } \\
\text { Cavlazoglu, and } \\
\text { Zeytuncu (2015) }\end{array}$ & nil & $\begin{array}{l}\text { “...the majority of students }(81 \%) \\
\text { indicated that flipped classroom videos } \\
\text { helped them feel more confident." (p. } \\
\text { 147) }\end{array}$ & Confidence $(+)$ & & & & $\bullet$ \\
\hline $\begin{array}{l}\text { Hwang and Lai } \\
(2017)\end{array}$ & $\mathrm{TFC}^{13}$ & $\mathrm{~F}=0.04, \mathrm{p}>.05$ & self-efficacy (0) & & $\bullet$ & $\bullet$ & \\
\hline $\begin{array}{l}\text { Boevé et al. } \\
\text { (2017) }\end{array}$ & $\begin{array}{l}\text { Exists, no } \\
\text { detail was } \\
\text { mentioned }\end{array}$ & $\begin{array}{l}\text { "positive experience in the regulation of } \\
\text { learning...were outnumbered by the } \\
\text { amount of students with negative } \\
\text { experiences" (p. 1025) }\end{array}$ & f Perception (-) & $\bullet$ & $\bullet$ & & \\
\hline Strayer (2012) & $\begin{array}{l}\text { direct } \\
\text { teaching }+ \\
\text { interactive } \\
\text { questions } \\
\text { and answer } \\
\text { sections }\end{array}$ & $\begin{array}{l}\text { "...students in the inverted classroom } \\
\text { commented mainly on the negative } \\
\text { things that the loose atmosphere } \\
\text { brought to the classroom, whereas } \\
\text { students in the traditional classroom } \\
\text { talked mainly about the positive things } \\
\text { that the loose atmosphere brought to } \\
\text { the class..." (p. 188) }\end{array}$ & Satisfaction (-) & $\bullet$ & & $\bullet$ & \\
\hline
\end{tabular}

${ }^{*}$ Remarks: coloured areas represent the studies with a control group (tradition-lecture model)

Table 3. Effect of in-class components on academic performance and perception

\begin{tabular}{|c|c|c|c|c|c|c|c|}
\hline $\begin{array}{l}\text { Effect of Flipped } \\
\text { Classroom }\end{array}$ & $\begin{array}{l}\text { Effect of the } \\
\text { components }\end{array}$ & Lecture & $\begin{array}{c}\text { Solving problems } \\
\text { or homework }\end{array}$ & $\begin{array}{l}\text { Discussion / } \\
\text { group discussion }\end{array}$ & $\begin{array}{l}\text { Feedback from } \\
\text { teachers }\end{array}$ & Quiz & $\begin{array}{c}\text { Peer-collaborative } \\
\text { work }\end{array}$ \\
\hline $\begin{array}{l}\text { Without a control } \\
\text { group }\end{array}$ & $\begin{array}{l}\text { Academic performance } \\
\text { Perception }\end{array}$ & $\begin{array}{l}+ \\
+\end{array}$ & +++ & $\begin{array}{c}+++0 \\
+0\end{array}$ & $\begin{array}{c}0 \\
+0\end{array}$ & $\begin{array}{l}+ \\
+\end{array}$ & + \\
\hline $\begin{array}{l}\text { With a control group } \\
\text { (traditional teaching } \\
\text { approach) }\end{array}$ & $\begin{array}{l}\text { Academic performance } \\
\text { Perception }\end{array}$ & - & $\begin{array}{l}+00 \\
++-\end{array}$ & ++ & ++ & & $\begin{array}{c}++ \\
+\end{array}$ \\
\hline
\end{tabular}

construction of meanings and individual progress towards reaching higher levels of development (Guitert \& Pérez-Mateo, 2013, p. 24).

Since the nature of the six activities may not be mutually exclusive, two or more types of activities could be identified in one action. For instance, students worked collaboratively on problems was counted as both solving problems or homework and peer-collaborative work.

In order to answer RQ3, the relationship between the effect on academic performance, perception and in-class activity should be found. Therefore, the effect on academic performance and perception, which were represented by the symbol " + ", " 0 " and "-", and the inclass activities adopted in the 12 articles were summarized in Table 3 according to the experiment design (with or without control group). Since the onegroup pretest-posttest design aims at measuring the gains between the pretest and posttest, it provides information about the effectiveness of mathematics flipped class. On the other hand, the two-group pretestposttest design aims at measuring the difference of the

${ }^{11}$ For convenient comparison purpose, the articles are sorted by "Perception" and the existence of a (non-flipping) control group (positive effect $\&$ with a control group, positive effect \& without a control group, no change or unclear effect \& without a control group, negative effect \& with a control group. Since no change or unclear effect \& with a control group and negative effect \& without a control group were not found, these two categories are omitted) followed by the alphabetical order of the name of the first author.

12 "Lecture" refers to in-class direct teaching

${ }^{13}$ Hwang \& Lai (2017) compared the effect between flipped classroom using e-book and traditional flipped classroom (TFC). TFC was assigned as the control group. 
Table 4. Common practice of the use of pre-class material in flipped classroom ${ }^{14}$

\begin{tabular}{lll}
\hline Articles & Pre-class material & Duration of the pre-class video \\
\hline Strayer (2012) & intelligent tutoring system (ALEKS) & Not mentioned \\
McGivney-Burelle and Xue (2013) & Videos + 5-10mins quiz & 3 videos (total 15mins) \\
Sahin, Cavlazoglu, and Zeytuncu (2015) & Video, such as YouTube & 10 mins* \\
Yousefzadeh and Salimi (2015) & Video prepared by the teachers & Not mentioned \\
Bhagat Chang, and Chang (2016) & Recorded video & $15-20$ mins $^{*}$ \\
Muir and Geiger (2016) & Video & $7-8 \mathrm{mins}^{*}$ \\
Boevé et al. (2017) & 15mins video with a hand in question answered & $15 \mathrm{mins}$ \\
Buch and Warren (2017) & Video & 15 mins \\
Hwang and Lai (2017) & e-books including the instructional videos, quizzes and learning & Not mentioned \\
Lo and Hew (2017) & guidance provided by the teacher & $<6$ mins \\
Song and Kapur (2017) & Video with a problem solved in the video (quiz) & 10 mins \\
Zengin (2017) & Video & Not mentioned \\
\hline
\end{tabular}

${ }^{*}$ : positive comment were observed on the duration of the video

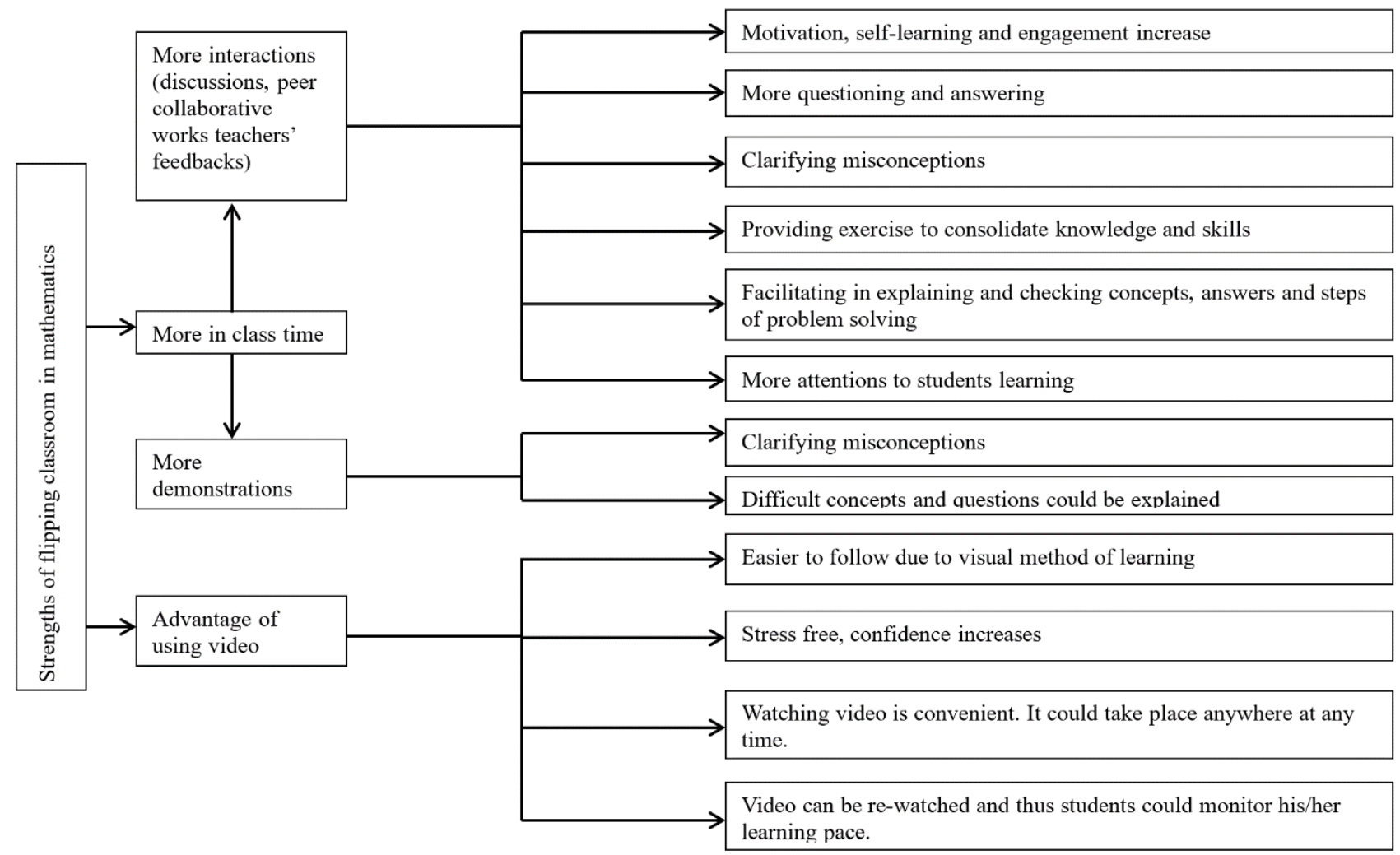

Figure 6. Strengths of flipped classroom in mathematics

gains between the sample and control group, and thus it provides information about the effectiveness of mathematics flipped class compared to the control groups (traditional approach). For example, a "+" was observed in the row "without control group-academic performance" under the column "lecture". It represents that the effectiveness of mathematics flipped class is positive. The flipped class could enhance students' academic performance in learning mathematics. Detailed analysis was done in the result sections. The practices of the use of pre-class material were summarized in Table 4 to answer RQ4. To provide a better picture about the strengths and weaknesses of using flipped classroom in mathematics, Appendix B and $C$ were made by summarising the strengths and weaknesses stated in the 12 articles. A flowchart was given in Figure 6 to show the logical flow of the data which was shown in Appendix B.

\section{BACKGROUND INFORMATION}

According to Figure 2, flipped classroom is now getting more and more popular and the USA dominates the publication. It shows that the earliest flippingclassroom-study in mathematics took place in 2012 and the rate of publication was relatively steady at one or two per year until 2016. A sharp peak was observed in 2017 with the number of publication increased to 7 publications per year. In the meantime, Figure 3 shows that the majority of the publication was produced by

${ }^{14}$ The articles are sorted by year of publication followed by the alphabetical order of the name of the first author. 
America $(n=4)$ and Taiwan $(n=2)$. According to Figure 4 and 5 , the majority seems to focus on the university level $(n=6)$ and the most frequently chosen topic were Precalculus or Calculus $(n=4)$. Details of the background information could be found in Appendix A.

\section{RESULTS AND ANALYSES}

\section{RQ1: Effect of Flipped Classroom on Academic Performance in Mathematics is Still Unclear}

As shown in Table 1, nine out of fourteen literature contained the results of the effects of the flipped classroom on the students' academic performance in mathematics. Five of them were conducted by using the one-group pretest-posttest design while four were conducted by using the two-group pretest-posttest design.

Results indicated that flipped classroom could produce a positive effect on students' academic performance in mathematics. Four out of five studies of the one-group pretest-posttest design reported a significant increase in the posttest. It suggested that flipped classroom is useful in enhancing students' mathematics performance.

However, there was a lack of strong evidence to conclude if flipped classroom would do better than the traditional approach. Although six out of nine studies reported positive effect, four of them were lack of a control group. For further analysis, the four two-group pretest-posttest design studies were extracted and compared (see the coloured row in Table 1). According to the current findings (one positive, one slightly positive and two unclear), the advantage of flipped classroom over the traditional approach was still unclear in terms of students' mathematics performance. Since the adopted in-class activities may be the reason for the academic improvement (Zuber, 2016), further analysis of the relationship between academic performance and inclass activities were made in the later sections.

\section{RQ2: Effect on Students' Perception is Still an Issue}

As shown in Table 2, eight out of fourteen literature contained the results about the effects of flipped classroom on the students' perceptions in mathematics. Five of them were conducted with a control group of the traditional approach. All studies without a control group reported a positive effect which suggested that flipped classroom could enhance perceptions, especially in terms of confidence.

However, whether flipped classroom could increase students' perceptions compared to the traditional approach was still an issue. Among the studies with a control group, three favoured while two opposed the use of flipped classroom. Such inconsistency suggested that the effect of flipped classroom on students' perceptions was unclear too. Reasons for such phenomena were discussed in the next section.

\section{RQ3: Effect of In-Class Components}

As stated in the previous two sections, the effect of flipped classroom, both on academic achievement and perceptions, is still unclear. Since the learning outcomes may depend on the teaching activities, the wide variety of in-class activity may be the reason for the inconsistency of the results. In other words, some inclass activities were more helpful in enhancing academic achievement and perceptions in mathematics while others were not. According to Table 3, six observations were found as the followings:

1. In-class lecture of flipped classroom in mathematics is useful to both academic performance and perception, but it could have a negative result compared to the traditional approach. It implies that in-class lecture may not be necessary for mathematics lesson or it should be used with cautions.

2. Solving problems or homework is effective in enhancing students' academic performance in mathematics; however, it is still unclear whether it could make extra learning gains, in both performance and perception, compared to the traditional approach.

3. Discussion is effective in enhancing academic performance in mathematics flipped classroom and it is more effective even though it is compared to the traditional approach. However, its effect on perception is not clear.

4. Feedback could enhance academic performance and it is more effective than the traditional approach, but its effect on perception was still unclear compared to the traditional approach.

5. Quiz could enhance both students' academic performance and perception. However, its effect compared to the traditional approach has not yet been studied.

6. Collaborative work is useful in enhancing students' academic performance. It is also useful in enhancing both academic performance and perception in mathematics flipped classroom compared to the traditional approach.

Effective mathematics flipped classroom always consists of discussion, feedback from teachers and peercollaborative work.

Interestingly, it is observed that all studies, which reported an academic improvement over the traditional approach, had applied discussion, teachers' feedback and peer-collaborative work as their in-class activities (see Table 1). The learning gains of discussion, teachers' feedback and peer-collaborative work in flipped classroom on students' mathematics academic 
performance is much more significant than solving problems when compared to traditional approach, (see Table 3). Since discussion, teachers' feedback and peercollaborative work are all interactions, it implies that interactions may be the essential element for effective flipped classroom in mathematics. Interactions may be the fundamental reason of using flipped classroom instead of the traditional approach.

\section{RQ4: The Common Practice of the Use of Pre-class Material and Video}

Table 4 shows a summary of the use of pre-class material in the reviewed literature. According to the literature, video was not the only component used in the pre-class section. Five out of twelve studies had applied homework problems or homework as supplementary material to the video. The range of duration of the video varied from 6 minutes to 20 minutes. The videos used were produced by the teachers, extracted from the internet or embedded in computer software. Interestingly, two out of twelve studies attempted to investigate the effectiveness of a modified flipped classroom approach by either using e-book or watching the video after the lectures. It indicated a trend of searching for new pre-class material for flipped classroom in mathematics.

\section{Brief Summary of the Strengths and Weaknesses of Using Flipped Classroom in Mathematics}

As shown in Figure 6 which summarised the strengths of the flipped classroom in mathematics stated in the 12 articles, the increase in in-class demonstration, the increase in interactions and the advantage of using video are the three main factors contributing to the advantage of using flipped classroom in mathematics.

Flipped classroom allows more demonstration so that difficult concepts and questions can be explained in class. It provides students with a deeper and broader understanding while misconceptions would be clarified (Lo \& Hew, 2017b; Muir \& Geiger, 2016; Zengin, 2017). In the meantime, flipped classroom allows more discussions, collaborative peer works and teachers' feedbacks so that more question and answering can be conducted (Lo \& Hew, 2017b; McGivney-Burelle \& Xue, 2013; Song \& Kapur, 2017; Yousefzadeh \& Salimi, 2015). More attention can be given to students learning instead of direct teaching in front of the blackboard (Bhagat Chang \& Chang, 2016; Hwang \& Lai, 2017; Song \& Kapur, 2017). They also provide students with the platform to consolidate their knowledge and skills (Lo \& Hew, 2017b). By facilitating students in explaining and checking concepts, answers and steps of the problemsolving process (Lo \& Hew, 2017b), understandings are enhanced (Strayer, 2012; Yousefzadeh \& Salimi, 2015) and misconceptions are clarified too (McGivney-Burelle \& Xue, 2013; Muir \& Geiger, 2016; Yousefzadeh \& Salimi,
2015). Moreover, video is a better method of learning than textbook. It allows learning to take place anywhere at any time (Lo \& Hew, 2017b; Song \& Kapur, 2017) without stress (McGivney-Burelle \& Xue, 2013; Sahin et al., 2015). It enhances student's awareness of his/her learning pace (Bhagat et al., 2016; Hwang \& Lai, 2017; Lo \& Hew, 2017b; McGivney-Burelle \& Xue, 2013; Muir \& Geiger, 2016; Song \& Kapur, 2017). Due to the visual method of learning, learning by using video is effortless for students to follow and understand the concepts (Boevé et al., 2017; Lo \& Hew, 2017b; McGivney-Burelle \& Xue, 2013; Muir \& Geiger, 2016; Sahin et al., 2015; Zengin, 2017). For detail, please refer to Appendix B.

On the other hand, results also revealed the drawbacks of using flipped classroom in mathematics. The lack of support (Bhagat et al., 2016; Lo \& Hew, 2017b) and regulation (Boevé et al., 2017; Muir \& Geiger, 2016; Strayer, 2012) in watching the videos are the two most frequently cited problems. Preparing the video is very time consuming (McGivney-Burelle \& Xue, 2013; Muir \& Geiger, 2016) while using video from others may lead to an inconsistency with the in-class material (Strayer, 2012). If the pre-class materials explain concepts and procedures differently from the instructors, students may feel fluctuation and lost in-class. As a consequence, the effectiveness of learning decrease (Strayer, 2012). For detail, please refer to Appendix C.

\section{DISCUSSIONS AND RECOMMENDATIONS}

\section{A Simple Reverse of Lecture/HW Order does not Work for Flipped Classroom}

Traditional views see the most distinctive characteristics of flipped classroom is the reverse order of the lecture and homework sequence; however, it is not sufficient to represent the flipped classroom. According to Table 1, the students in the two studies, which achieved flipped classroom by merely reversing the lecture-homework order and applying solving-problem as the only in-class activity, did not show significant improvement compared with the traditional teaching approach.

Every coin has two sides. Replacing the traditional direct teaching part with video can result in several advantages; however, it leads to some critical disadvantages in mathematics learning too. Although using video could enhance students understanding (McGivney-Burelle \& Xue, 2013; Muir \& Geiger, 2016; Sahin et al., 2015; Zengin, 2017), match students' individual learning pace (Bhagat et al., 2016; Lo \& Hew, 2017b; McGivney-Burelle \& Xue, 2013; Song \& Kapur, 2017), provide pre-requisite knowledge for the in-class activities (Lo \& Hew, 2017b; McGivney-Burelle \& Xue, 2013), reduce limitations (such as geographical limitation) to learning (Song \& Kapur, 2017) and increase 
autonomy (Muir \& Geiger, 2016), the drawbacks are critical in hindering the efficacy of mathematics learning. The video extracted from the internet (such as YouTube or TED) is usually made by some amateurs. They may not be trained on how to properly access, identify, gather, and synthesise information by using information technology and thus the quality of the video may be problematic (Graziano, 2017). The different style in explaining the concepts and procedures between the video and the instructor create confusion in students learning too (Strayer, 2012). For example, nonmathematics experts may interpret the terms "understanding the multiplication table" as "memorizing the multiplication table" and thus they may create videos which ask students to memorize the table simply; however, mathematics educators see application, analysis, synthesis and evaluation are all included in "understanding" (e.g., Bloom, 1956). Therefore, experts would emphasise more on the mathematical meanings; for instance, what does " $7 \times 8$ " mean and how it could be derived. Students will be demonstrated that " $5 \times 8$ ", " $6 \times 8$ " and " $7 \times 8$ " represent the sum of five "eights", six "eights" and seven "eights" respectively. By asking them the relationships between " 40 ", " 48 ", a logical sequence was developed and the answer " 56 " could be deduced by themselves. The depth of learning provided by quality videos is much deeper.

Meanwhile, students could find no supports when they encounter problems during watching videos (Lo \& Hew, 2017b). Unlike other subjects, mathematics is a subject which requires a lot of pre-requisite knowledge. In the previous example, students could hardly deduce a correct conclusion if he has no idea about the relationship between summation and multiplication (e.g., " $5 \times 8=8+8+8+8+8$ ") during watching the video. Finally, many studies reported that students might not do homework or watch videos at home unless they were told to do or the deadline of the exam is near (Muir \& Geiger, 2016; Strayer, 2012). Problems and misconceptions will be accumulated and the learning of additional knowledge will be affected (Nadelson et al., 2013).

Consequently, the advantages and disadvantages cancelled each other and thus a simple re-ordering of the teaching activities of lecture and solving problems does not yield extra benefits for flipped classroom in mathematics learning.

\section{The Use of Lecture as an In-class Component in Mathematics Flipped Classroom}

What in-class activity should be used has been fallen into a debate for many years (Giannakos et al., 2014 Kostaras, 2017; Zuber, 2016). Many researchers skipped the lecture and started their planned activities (such as discussion, solving problems, etc.) immediately in the in- class section of the flipped classroom (See Table 3). Is inclass lecture necessary to flipped classroom?

Interestingly, the result suggests that in-class lecture is useful to flipped classroom to a certain extent. First, students want it. Boevé et al. (2017) reported that there is a conflict between what students want and what works. Although both educators and students are aiming at implementing more active learning component, intriguingly, students tend to focus more on the negative effects of active learning while more on the positive effects of passive learning (Strayer, 2012). Passive explanation is indeed desired by students (Boevé et al., 2017). Meanwhile, students need it. Many educators reported that one of the biggest problems in flipped classroom is the lack of regulation in the pre-class section. Therefore, quiz or problems were assigned together with the video; however, the status quo is still not satisfactory (Boevé et al., 2017; Muir \& Geiger, 2016; Strayer, 2012, and Table 4). If in-class activities such as discussion are conducted immediately, students may feel lost if instructions are not given clearly (Strayer, 2012). However, a comprehensive in-class lecture repeating all materials in the video would be definitely not appropriate because the general purpose of the use of video in flipped classroom is to provide the subject knowledge (Song \& Kapur, 2017). Therefore, an in-class lecture which consists of a very short revision and instructions of the following in-class activities are suggested to be used in flipped classroom. It could also develop the fundamental pre-requisites knowledge for those students who are unable or forget to watch the preclass video before the lecture.

\section{The Use of Interactions to Enhance the Learning Efficiency in Mathematics Flipped Classroom}

Learning mathematics is difficult because it requires a lot of logical reasoning, clear concepts as well as a correct planning strategy (Gafoor \& Sarabi, 2015; Kosko \& Miyazaki, 2012). For example, to solve the question "whether the point $(1,2)$ is located inside, outside or on the circle $(x-1)^{2}+(y-3)^{2}=2^{2 \prime \prime}$, students have to understand the " 1 ", " 3 " and " 2 " in the circle equation representing the circle which has a centre at $(1,3)$ with a radius of " 2 ". If $(1,2)$ is substituted into the equation $(x-1)^{2}+(y-3)^{2}$ such that $(1-1)^{2}+(2-3)^{2}=1^{2}$, the " 1 " on the right-hand side represent the distance of $(1,2)$ from the circle centre $(1,3)$. By comparing the distance from the centre and the radius and observing that $1<2$, a conclusion of $(1,2)$ is located inside the circle $(x-1)^{2}+(y-3)^{2}=2^{2}$ is drawn. If one single step/concept goes wrong, the correct answer is very unlikely to be achieved.

Therefore, unlike other subjects, students could not answer advanced problems by themselves. It requires more external supports to clarify the concepts, clear misunderstanding, organise the reasoning and justify 

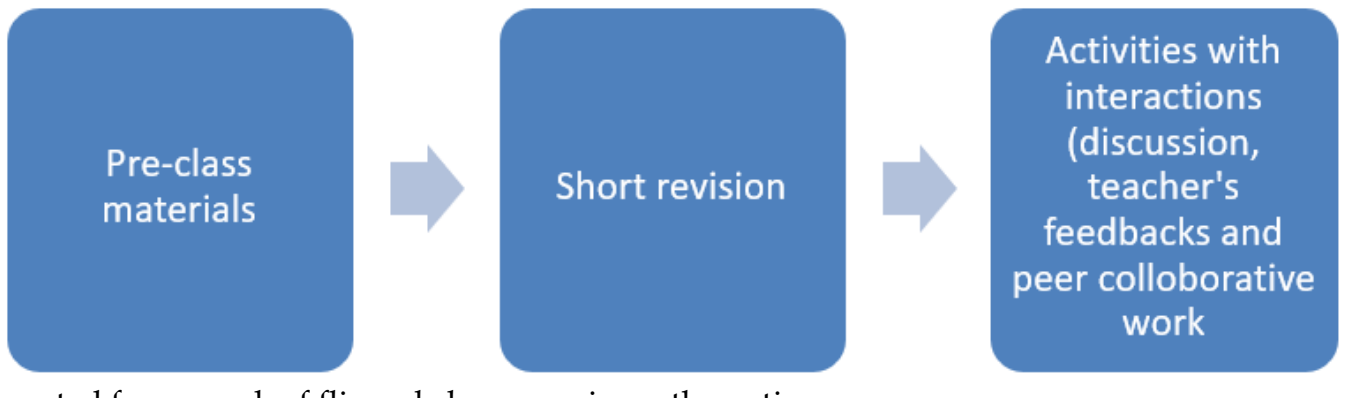

Figure 7. A suggested framework of flipped classroom in mathematics

the planning strategies (Gafoor \& Sarabi, 2015; Kosko \& Miyazaki, 2012; Lo \& Hew, 2017b). For instance in the previous example, through the peer-collaborations, students could be asked by their peers why $1<2$ should be compared. It clarifies the reasoning and justifies the planning. Further example, $(1-1)^{2}+(2-3)^{2}=1^{2}$ represents the formula which is used to find out the distance between two points in Geometry; however, it could represent another circle which has a centre at $(1,3)$ with a radius of " 1 " too. By raising this question and discussing it with peers and teachers, students would know more about the facts that both the circle equation and the distance between two points formula come from the Pythagoras' theorem, and thus they have similar formats. It would clear the misunderstanding and establish further logical connections between mathematics topics.

Traditional teaching method may include interactions too, but flipped classroom could embed more interactions, and thus the efficiency of learning mathematics could be further. As shown by Bhagat et al. (2016) work, traditional teaching method (see the control group) may spend more than half of the lesson for direct teaching and thus the time left for interactions is very limited. Usually, only one activity could be introduced. By shift the direct teaching out of the classroom, flipped classroom allows the use of more than one interactive activities and hence produce a more significant learning effect.

\section{Recommendation to Flipped Classroom in the Future: A Suggested Framework for Flipped Classroom in Mathematics and Interactive Pre-class Materials}

In light of the above, it is believed that a general and successful flipped classroom in mathematics should include a pre-class material, an in-class revision and interactions such as discussion, teacher' feedbacks and peer collaborative work (Figure 6).

However, Song and Kapur (2017) argued that the purpose of the use of pre-class material (video) is a critical factor determining the result of the flipped classroom. Non-interactive video performed better in enhancing students' procedural knowledge while the interactive material did better on promoting students' conceptual knowledge. Therefore, a matching of the proposes between the components is also required. Furthermore, Song and Kapur's (2017) work also enlightened the possibilities for the searching for alternative pre-class materials with their corresponding in-class activities for different teaching purposes.

\section{The Introducing of Flipped Classroom Should be Appropriate and Less Radical Changes should be Made}

Although the use of flipped classroom in mathematics would lead to several advantages, the result suggested that the introducing of flipped classroom should not be too radical. Students need time to adapt to flipped classroom which is a relatively new pedagogy to them (Strayer, 2012). There are still demand the passive explanation and the regulation for students' learning (Boevé et al., 2017). A sudden change from the traditional approach to the flipped classroom may result in negative feelings due to the unfamiliarity of the instructions, teaching content among students. A relaxed atmosphere will thus be formed, as a result, it hinders the learning outcomes (Boevé et al., 2017; Strayer, 2012).

\section{CONCLUSION AND LIMITATIONS}

This study reviewed 12 articles of flipped classroom in mathematics. Results revealed that the effect of flipped classroom in enhancing students' academic performance and perception is still an issue. Although flipped classroom is an effective alternative teaching and learning strategy, the evidence is still not strong enough to conclude whether flipped classroom is better than the traditional approach in terms of students' academic performance and perception.

The six in-class flipped classroom activities in mathematics identified by this review are lecture, solving problems, discussion, teachers' feedbacks, quiz and peer-collaborative work. Further investigation showed that effective flipped classroom, which yielded a better result than the traditional approach, always consists of discussion, teachers' feedbacks, quiz and peer-collaborative work. It implies that interactions may indeed be the fundamental reasons for using flipped classroom in mathematics because the learning of mathematics requires many interactions to clarifying the 
misconceptions and justifying the concepts and ideas. It is also essential for students to solve and achieve advanced mathematical problems and goals.

Results also suggested that a simple reverse of lecture and homework sequence does not yield any advantage for flipped classroom over the traditional approach. Although there are several benefits by using video for the direct instruction, there are drawbacks when shifting it into the pre-class section. Again, without support from teachers and peers, the learning gain from flipped classroom is indistinguishable from the traditional approach.

On the other hand, the result also suggested that revision is useful to flipped classroom. Although active learning components are the main focus, a short revision is essential because instructions should be made explicit and pre-requisite knowledge should be provided for ensuring the quality of the active learning components. Without them, students will easily get lost and lose their focus. As a consequence, the quality of learning decreases.

Therefore, a general framework of flipped classroom in mathematics is summarised. To engender an effective flipped classroom, a pre-class material, an in-class revision and interactions such as discussion, teacher' feedbacks and peer collaborative work is need. Further research could be done in investigating if video could be replaced by alternative interactive pre-class materials to enhance the learning outcomes in mathematics.

However, extra cautions should be taken when interpreting the result of this research due to its small sample size, topics, cultural and geographical limitations. Further studies, especially flipped classroom study of different in-class activities, are needed for a comprehensive analysis. Meanwhile, the result might be biased since the majority of the studies are conducted in the USA, while about $60 \%$ of the topics studied are either algebra or calculus (including pre-calculus). In the meantime, limitation might also exist due to the publication biased (Bernard, Borokhovski, \& Tamim, 2014).

Author contributions: All authors have sufficiently contributed to the study, and agreed with the results and conclusions.

Funding: No funding source is reported for this study.

Declaration of interest: No conflict of interest is declared by authors.

\section{REFERENCES}

Attali, Y., \& Van Der Kleij, F. (2017). Effects of feedback elaboration and feedback timing during computerbased practice in mathematics problem solving. Computers \& Education, 110, 154-169. https://doi.org/10.1016/j.compedu.2017.03.012

Baker, J. W. (2000). The Classroom Flip: Using Web Course Management Tools to Become the Guide by the Side. Selected Papers from the 11th International
Conference on College Teaching and Learning, Jacksonville.

Bergmann, J., \& Sams, A. (2012). Flip your classroom: Read every student in every class every day. International Society for Technology in Education.

Bernard, J. S. (2015). The flipped classroom: fertile ground for nursing education research. International Journal of Nursing Education Scholarship, 12(1), 99-109. https://doi.org/10.1515/ijnes-20150005

Bernard, R. M., Borokhovski, E., \& Tamim, R. M. (2014). Detecting bias in meta-analyses of distance education research: big pictures we can rely on. Distance Education, 35(3), 271-293. https:/ / doi.org/ 10.1080/01587919.2015.957433

Bishop, J. L., \& Verleger, M. A. (2013). The flipped classroom: a survey of the research. In 120th ASEE National Conference and Exposition, Atlanta, GA (Paper ID 6219). American Society for Engineering Education.

Boevé, A. J., Meijer, R. R., Bosker, R. J., Vugteveen, J., Hoekstra, R., \& Albers, C. J. (2017). Implementing the Flipped Classroom: An Exploration of Study Behaviour and Student Performance. Higher Education: The International Journal of Higher Education Research, 74(6), 1015-1032. https: / / doi.org/10.1007/s10734-016-0104-y

Bloom, B. S. (1956). Taxonomy of educational objectives: the classification of educational goals (1st ed.). Longmans Green.

Bhagat, K. K., Chang, C. N., \& Chang, C. Y. (2016). The Impact of the Flipped Classroom on Mathematics Concept Learning in High School. Educational Technology and Society, 19(3), 134-142. http:/ / www. jstor.org/stable/jeductechsoci.19.3.134

Buch, G. R., \& Warren, C. B. (2017). The Flipped Classroom: Implementing Technology to Aid in College Mathematics Student's Success. Contemporary Issues in Education Research, 10(2), 109. 116. https:/ / doi.org/10.19030/cier.v10i2.9921

Chua, J. S. M., \& Lateef, F. A. (2014). The flipped classroom: viewpoints in Asian universities. Education in Medicine Journal, 6(4), 20-26. https://doi.org/10.5959/eimj.v6i4.316

Cooper, H.M. (2007). Evaluating and interpreting research synthesis in adult learning and literacy. National College Transition Network, New England Literacy Resource Center/World Education. https:/ / doi.org/10.1037/e549792010-001

Cooper, H. M. (2010). Research synthesis and meta-analysis: A step-by-step approach (4th ed.). Sage.

Crouch, C. H., \& Mazur, E. (2001). Peer instruction: ten years of experience and results. American Journal of Physics, 69(9), 970-977. https://doi.org/10.1119/ 1.1374249 
Delozier, S. J., \& Rhodes, M. G. (2017). Flipped classrooms: a review of key ideas and recommendations for practice. Educational Psychology Review, 29(1), 141-151. https:/ / doi.org/ 10.1007/s10648-015-9356-9

Dove, A., \& Dove, E., (2017). Flipping Preservice Elementary Teachers' Mathematics Anxieties. Contemporary Issues in Technology and Teacher Education (CITE Journal), 17(3), 312-335. https: / / www.learntechlib.org/p/171621/

Gafoor, K. A., \& Sarabi, M. K. (2015, November). Nature of Mathematics That Impacts Difficulties in Learning It: A Comparison of Student Perspectives on Learning School Subjects from Kerala [Paper presentation]. All India Association for Educational Research Annual cum International Conference on Standards and Benchmarks for Excellence in Learning, Teaching and Research, India.

Giannakos, M. N., Krogstie, J., \& Chrisochoides, N. (2014). Reviewing the flipped classroom research: reflections for computer science education. In Proceedings of the Computer Science Education Research Conference (pp. 23-29). ACM. https:/ / doi.org/10.1145/2691352.2691354

Gilboy, M. B., Heinerichs, S., \& Pazzaglia, G. (2015). Enhancing student engagement using the flipped classroom. Journal of Nutrition Education and Behavior, 47(1), 109-114. https://doi.org/10.1016/ j.jneb.2014.08.008

Gross, B., Marinari, M., Hoffman, M., DeSimone, K., \& Burke, P. (2015). Flipped @ SBU: student satisfaction and the college classroom. Educational Research Quarterly, 39(2), 36-52.

Graziano, K. J. (2017). Peer Teaching in a Flipped Teacher Education Classroom. TechTrends: Linking Research and Practice to Improve Learning, 61(2), 121-129. https: / / doi.org/10.1007/s11528-016-0077-9

Guitert, M., \& Pérez-Mateo, M. (2013). La colaboración en la red: hacia una definición de aprendizaje colaborativo en entornos virtuales [Collaboration on the web: towards a definition of collaborative learning in virtual environments]. Revista Teoría de la Educación: Educación y Cultura en la Sociedad de la Información, 14(1), 10-31

Hwang, G.-J., \& Lai, C.-L. (2017). Facilitating and Bridging Out-Of-Class and In-Class Learning: An Interactive E-Book-Based Flipped Learning Approach for Math Courses. Educational Technology and Society, 20(1), 184-197. http://www.jstor.org/ stable/jeductechsoci.20.1.184

Isabel B., Stefan R., \& Mikko V. (2014). Inverted Classroom by Topic - A Study in Mathematics for Electrical Engineering Students. International Journal of Engineering Pedagogy (iJEP), 4(3), 11-17. https:/ / doi.org/10.3991/ijep.v4i3.3299
King, A. (1993). From sage on the stage to guide on the side. College Teaching, 41(1), 30-35. https:/ / doi.org/10.1080/87567555.1993.9926781

Kosko, K., \& Miyazaki, Y. (2012). The Effect of Student Discussion Frequency on Fifth-Grade Students' Mathematics Achievement in U.S. Schools. The Journal of Experimental Education, 80(2), 173-195. https:/ / doi.org/10.1080/00220973.2011.566588

Kostaras, V. (2017). Flipped Classroom: A Literature Review on the Benefits and Drawbacks of the Reversed Classroom (Dissertation). http:/ / urn.kb.se/resolve? urn=urn:nbn:se:du-26281

Lelean, H., \& Edwards, F. (2020). The impact of flipped classrooms in nurse education. Waikato Journal of Education = Te Hautaka Mātauranga o Waikato., 25(1), 145-157. https:/ / doi.org/10.15663/wje.v25i0.735

Lin, H., \& Hwang, G. (2018). Research trends of flipped classroom studies for medical courses: A review of journal publications from 2008 to 2017 based on the technology-enhanced learning model. Interactive Learning Environments, 1-17. https://doi.org/ 10.1080/10494820.2018.1467462

Lo, C. K., \& Hew, K. F. (2017a). A critical review of flipped classroom challenges in K-12 education possible solutions and recommendations for future research. Research and Practice in Technology Enhanced Learning, 12(4), 1-22. https://doi.org/ 10.1186/s41039-016-0044-2

Lo, C. K., \& Hew, K. F. (2017b). Using “First Principles of Instruction" to Design Secondary School Mathematics Flipped Classroom: The Findings of Two Exploratory Studies. Educational Technology and Society, 20(1), 222-236. https://doi.org/ 10.18178 /ijlt.3.2.82-89

Mazur, E. (1997). Peer Instruction: A User's Manual Series in Educational Innovation. Prentice Hall.

McGivney-Burelle, J., \& Xue, F. (2013). Flipping Calculus. PRIMUS, 23(5), 477-486. https:/ / doi.org/ 10.1080/10511970.2012.757571

Muir, T., \& Geiger, V. (2016). The Affordances of Using a Flipped Classroom Approach in the Teaching of Mathematics: A Case Study of a Grade 10 Mathematics Class. Mathematics Education Research Journal, 28(1), 149-171. https://doi.org/10.1007/ s13394-015-0165-8

Nadelson, L. S., Callahan, J., Pyke, P., Hay, A., Dance, M., \& Pfiester, J. (2013). Teacher STEM Perception and Preparation: Inquiry-Based STEM Professional Development for Elementary Teachers. Journal of Educational Research, 106(2), 157-168. https: / / doi.org/10.1080/00220671.2012.667014

O'Flaherty, J., \& Phillips, C. (2015). The use of flipped classrooms in higher education: a scoping review. The Internet and Higher Education, 25, 85-95. https:/ / doi.org/10.1080/00220671.2012.667014 
Pierce, R., \& Fox, J. (2012). Instructional design and assessment: Vodcasts and active learning exercises in a "flipped classroom" model of a renal pharmacotherapy module. American Journal of Pharmaceutical Education, 76(10), 1-5. https:/ / doi.org/10.5688/ajpe7610196

Ramaprasad, A. (1983). On the definition of feedback. Behavioral Science, 28(1), 4-13. https://doi.org/ $10.1002 /$ bs.3830280103

Reninger, K., \& Rehark, L. (2009). Discussions in a Fourth-Grade Classroom: Using Exploratory Talk to Promote Children's Dialogic Identities. Language Arts, 86(4), 268-279. http://www.jstor.org/stable/ 41483537

Roehl, A., Reddy, A. L., \& Shannon, G. J. (2013). The flipped classroom: An opportunity to engage millennial students through active learning strategies. Journal of Family and Consumer Science, 105(2), 44-49. https://doi.org/10.14307/JFCS105. 2.12

Sahin A., Cavlazoglu, B., \& Zeytuncu, Y. E. (2015). Flipping a College Calculus Course: A Case Study. Educational Technology and Society, 18(3), 142-152. http:/ / www.jstor.org/stable/jeductechsoci.18.3.1 42

Song, Y., \& Kapur, M. (2017). How to Flip the Classroom - "Productive Failure or Traditional Flipped Classroom" Pedagogical Design? Educational Technology and Society, 20(1), 292-305. http:/ / www. jstor.org/stable/jeductechsoci.20.1.292

Strayer, J. F. (2012). How Learning in an Inverted Classroom Influences Cooperation, Innovation and Task Orientation. Learning Environments Research, 15(2), 171-193. https://doi.org/10.1007/s10984012-9108-4

Strelan, P., Osborn, A., \& Palmer, E. (2020). The flipped classroom: A meta-analysis of effects on student performance across disciplines and education levels. Educational Research Review. 30. https:/ / doi.org/10.1016/j.edurev.2020.100314

Van Alten, D. C.D., Phielix, C., Janssen, J., \& Kester, L. (2019). Effects of flipping the classroom on learning outcomes and satisfaction: A meta-analysis. Educational Research Review, 28, 100281. https:// doi.org/10.1016/j.edurev.2019.05.003
Van Vliet, E. A., Winnips, J. C., \& Brouwer, N. (2015). Flipped-class pedagogy enhances student metacognition and collaborative-learning strategies in higher education but the effect does not persist. CBE Life Science Education 14(3), 1-10. https:/ / doi.org/10.1187/cbe.14-09-0141

Vygotsky, L. S. (1978). Mind in Society: The Development of Higher Psychological Processes. Harvard University Press.

Vygotsky, L. S. (1987). Thinking and Speech. Plenum.

Ward, M., Knowlton, M. C., \& Laney, C. W. (2018). The flip side of traditional nursing education: A literature review. Nurse Education in Practice, 29, 163-171.

https:/ / doi.org/10.1016/j.nepr.2018.01.003

Webb, N. M., Franke, M. L., Ing, M., Turrou, A. C., Johnson, N. C., \& Zimmerman, J. (2017). Teacher practices that promote productive dialogue and learning in mathematics classrooms. International Journal of Educational Research, 1-11. https:/ / doi.org/10.1016/j.ijer.2017.07.009

Wagner, M., Gegenfurtner, A., \& Urhahne, D. (2021). Effectiveness of the Flipped Classroom on Student Achievement in Secondary Education: A MetaAnalysis. Zeitschrift Für Pädagogische Psychologie, 35(1), 11-31. https://doi.org/10.1024/10100652/a000274

Yousefzadeh, M., \& Salimi, A. (2015). The Effect of Flipped Learning (Revised Learning) on Iranian Students' Learning Outcomes. Advances in Language and Literary Studies, 6(5), 209-213. https:// doi.org/10.7575/aiac.alls.v.6n.5p.209

Zainuddin, Z., \& Halili, S. H. (2016). Flipped classroom research and trends from different fields of study. International Review of Research in Open and Distributed Learning, 17(3), 313-340. https://doi.org/10.19173/irrodl.v17i3.2274

Zengin, Y. (2017). Investigating the Use of the Khan Academy and Mathematics Software with a Flipped Classroom Approach in Mathematics Teaching. Educational Technology and Society, 20(2), 89-100. http:/ / www.jstor.org/stable/90002166

Zuber, W. J. (2016). The flipped classroom, a review of the literature. Industrial and Commercial Training, 48(2), 97-103. https://doi.org/10.1108/ICT-052015-0039 
APPENDIX A

\section{Summary of Background Information}

\begin{tabular}{|c|c|c|c|c|}
\hline Author(s), Year & $\begin{array}{l}\text { Participants \& } \\
\text { Sample Size } \\
\text { (Sample / } \\
\text { Control) } \\
\end{array}$ & Research Design & $\begin{array}{l}\text { Model of Flipping } \\
\text { S: sample group } \\
\text { C: Control Group } \\
\text { (Out-of-class / In-class) } \\
\end{array}$ & Reported Outcomes \\
\hline Strayer (2012) & $\begin{array}{l}\text { University } \\
(26 / 23)\end{array}$ & $\begin{array}{l}\text { Quasi- } \\
\text { experimental }\end{array}$ & $\begin{array}{l}\text { S: intelligent tutoring system (ALEKS) / a } \\
\text { number of learning activities (e.g. } \\
\text { investigation of a fictitious business or a } \\
\text { spreadsheet programme) + free interactions } \\
\text { with the instructor } \\
\text { C: direct teaching + interactive questions } \\
\text { and answer sections }\end{array}$ & $\begin{array}{l}\text { Students in flipping classroom had le } \\
\text { satisfaction compared to traditional } \\
\text { approach. }\end{array}$ \\
\hline $\begin{array}{l}\text { Mcgivney-Burelle } \\
\text { and Xue (2013) }\end{array}$ & $\begin{array}{l}\text { University } \\
(31 / 29)\end{array}$ & $\begin{array}{l}\text { Quasi- } \\
\text { experimental }\end{array}$ & $\begin{array}{l}\text { S: } 3 \text { videos total } 15 \mathrm{mins}+5-10 \mathrm{mins} \text { quiz / } \\
\text { working on problems } \\
\text { C: direct teaching + notes taking }\end{array}$ & $\begin{array}{l}\text { Students' academic performance of } \\
\text { flipping classroom was higher than } \\
\text { traditional approach (no t test, just } \\
\text { simple compare the means). } \\
\text { Students in flipping classroom had } \\
\text { higher satisfaction compared to } \\
\text { traditional approach. }\end{array}$ \\
\hline
\end{tabular}

and Zeytuncu

(2015)

Yousefzadeh and Elementary

Salimi (2015) (25/25)

Muir and Geiger

(2016)

Bhagat, Chang,

Middle School Quasi-

and Chang (2016) (41/41)

\section{experimental}

lecture / surveys and pop quizzes increased.

Confidence in learning increased.

Quasi-

experimental

S: video / exercises + projects + discussion + teachers' feedback

C: not mentioned

Students' academic performance of flipping classroom was higher than traditional approach.

Students' confidence increased. demonstrations or explanations + examples and problems on their iPads with the teacher assisting

S: A recorded 15-20 mins video / Students were divided into groups to discuss the textbook problems + face-to-face remedial assistance

C: $30-40$ mins lecture and discussion $+10-20$ confidence and satisfaction increased. mins solving problems

Hwang and Lai Elementary Quasi-

$(2017) \quad(24 / 21)$

experimental

S: interactive e-book-based instructional videos, quizzes and learning guidance /

Interactive e-book-based flipping classroom resulted in better academic C: conventional video / group discussion + question and answering

performance than traditional flipping

classroom.

No change in self-efficacy.

Song and Kapur Middle School (2017) $(25 / 25)$

Boevé et al. (2017) University Quasi(205/295) experimental

S: 10 mins video / discussion + question and answering + solving problems C: discussion + solving problems + clarifying questions

FFC could result in a better academic performance than TFC in terms of conceptual understanding.

S: 15 mins video with an assigned question / Students' perceptions in flipping answer the problem + discussion classroom decreased C: not mentioned

No observable change in study behavior could be identified.
Zengin (2017) University (28) Pre-Experimental S: video (Khan) / GeoGebra + discussion + solving problems

Buch and Warren University Quasi- S: 15 mins video / solving problems

(2017) (62/28)

experimental

C: direct lecture

Students' academic performance increased.

Students' academic performance of flipping classroom was higher than traditional approach.

Students' confidence increased

Lo and Hew (2017) High School (13 Pre-Experimental S: <6mins video with an assigned problem / Students' academic performance and 24) 15 clarify misconceptions + solving problems + increased

group discussion

15 This article contains two studies: study 1 and 2.13 and 24 refers to the sample sizes of the study 1 and 2 respectively. 


\section{APPENDIX B}

\section{Strengths of the Use of Flipping Classroom in Mathematics Learning}

Strengths of flipping classroom
Flipping classroom allows more discussion so that more questioning and answering
could be done in class.

Flipping classroom free up in-class time thus increase class demonstration, especially the difficult concepts and questions.

Flipping classroom can free up in-class time thus increase time for clarifying students' misconceptions

Lower achievers get attention from teachers.

Due to the increase of interactions, motivation and self-learning engaging increase.

Flipping classroom allows more peer and collaborative work so that students could facilitate in explaining and checking concepts, answers and steps of problem solving each other.

Flipping classroom allows more peer and collaborative work which provide exercise to Lo and Hew (2017) consolidate their knowledge and skills.

Flipping classroom allows more teachers' feedback which students usually appreciate.

The immediate feedback that takes place in the flipped classroom helps students recognize and think about their own increasing understanding instead of remembering what it is written on the blackboard.

Watching video is easier to following the video than textbook due to the visual method Boevé et al. (2017); Lo and Hew (2017); McGivneyof learning.

Video can be re-watched and thus students could monitor his/her learning pace.

Watching video is stress-free and it increase students' confidence

Watching video is convenient. It could take place anywhere at any time.

\section{Articles}

Lo and Hew (2017); McGivney-Burelle and Xue (2013);

Song and Kapur (2017); Yousefzadeh and Salimi (2015)

Lo and Hew (2017); Muir and Geiger (2016); Zengin (2017)

McGivney-Burelle and Xue (2013); Muir and Geiger (2016); Yousefzadeh and Salimi (2015)

Bhagat, Chang, and Chang (2016); Hwang and Lai (2017); Song and Kapur (2017)

Lo and Hew (2017)

Lo and Hew (2017)

Strayer (2012)

Strayer (2012); Yousefzadeh and Salimi (2015) Burelle and Xue (2013); Muir and Geiger (2016); Sahin, Cavlazoglu, and Zeytuncu (2015); Zengin (2017)

Bhagat, Chang, and Chang (2016); Hwang and Lai (2017); Lo and Hew (2017); McGivney-Burelle and Xue (2013); Muir and Geiger (2016); Song and Kapur (2017) McGivney-Burelle and Xue (2013); Sahin, Cavlazoglu, and Zeytuncu (2015)

Lo and Hew (2017); Song and Kapur (2017) 


\section{APPENDIX C}

\section{Weaknesses of the Use of Flipping Classroom}

\begin{tabular}{ll}
\hline Weaknesses of flipping classroom & Articles
\end{tabular}

Pre-class materials are inconsistence with in class materials. They sometimes explained Strayer (2012)

concepts and procedures differently from the instructors. Students feel lost in-class (in

flipping classroom) because they have no idea of what the instructor is going to do.

More passive explanation was desired.

Boevé et al. (2017)

Lack of student regulation in watching video. Mostly reported watching video lectures right before the exam. Students might use video but they usually use them only when teacher ask them.

Lack of support when watching video

Boevé et al. (2017); Muir and Geiger (2016); Strayer (2012)

Bhagat, Chang, \& Chang (2016); Lo and Hew (2017)

Preparing video is time consuming. On average it tool 1.5hr to make a video with 45mins McGivney-Burelle and Xue (2013); Muir and Geiger for quiz problem set etc.

(2016)

\section{http://www.ejmste.com}

